\title{
Indonesia Influencers in Social Media Advertising: Opportunities and Threats
}

\author{
$1^{\text {st* }}$ Daniel Paulus Evert \\ Communication Science Department \\ Universitas Sangga Buana \\ Bandung, Indonesia \\ Daniel.matulessy@usbypkp.ac.id
}

\author{
$2^{\text {nd }}$ Reza Saeful Rachman \\ Communication Science Department \\ Universitas Sangga Buana \\ Bandung, Indonesia \\ Reza.saeful@usbypkp.ac.id
}

\begin{abstract}
This research is motivated by the phenomenon of the widespread use of social media influencers in various activities in Indonesia, especially in the field of advertising. This research employed a qualitative approach. The results show there are opportunities such as cheaper advertising cost, marketers plan to increase their social advertising budgets and trust from the followers. Besides opportunities, there are also threats likes influencers' ability to produce quality content continuously, third-party agencies, income taxes and the emergence of other influencers.
\end{abstract}

Keywords - influencers, social, media, advertising, opportunities, threats

\section{INTRODUCTION}

The development of social media such as Instagram, Facebook, Twitter and YouTube have changed marketing strategies. The rise of social media users eventually led to a change in the marketer's ad approaches. For example, in the past the reliance on promotions was only related to conventional information products such as television, newspapers, or radio. Businesses prefer to market their products and services through social media. The cost of advertising, which was originally centered on various conventional media, is now largely allocated for social media advertising. This is confirmed by the data from GetCRAFT, a marketing firm based in Southeast Asia, in its report titled "Indonesia Native Advertising and Influencer Marketing Report 2018" which states that Indonesians consume more social media than TV. The number reaches 3 hours 16 minutes compared to 2 hours 23 minutes [1].

Instagram becomes a medium of information delivery, where information can be conveyed without having to write a lengthy series of articles. Users are presented with real experiences through a series of pictures and videos, so the marketers have more option to create more attractive ad content.

Michael Ray [2] define promotional activity as the coordination of all seller-initiated efforts to setup channels of information and persuasion to sell goods and services or promote an idea. The opportunity was captured with caution by advertisers and advertising agencies until finally there was a social media advertising ecosystem where influencers became a factor that influenced consumers in product purchase decisions. The use of Influencers in advertising is caused by one factor, namely the assumption that influencers are more than just artists but are now a role model for some young people in Indonesia.

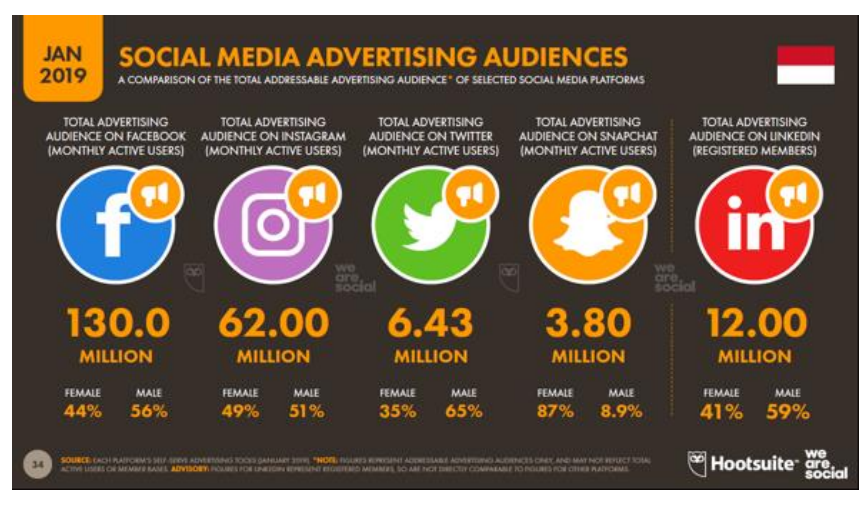

Fig. 1. Social Media Advertising Audiences in Indonesia https://datareportal.com/reports/digital-2019-indonesia

Based on data from We Are Social above, the total advertising audience (monthly active users) on Facebook is 130 million, 62 million for Instagram, 6.43 million for Twitter, and 3.8 million for Snapchat. An attractive market niche for influencer marketing. Advertising is very influential on a sales activity. Besides choosing the right media and ad stars to advertise will add to the effectiveness of the ad. But in reality, the use of influencers as ad stars encountered various problems both internal and external. Therefore, this paper will explain how the opportunities and challenges of using influencers in advertising on Instagram.

\section{LITERATURE REVIEW}

Advertising is a paid, mass-mediated attempt to persuade [3]. The definition explained that one of advertising's goal is how to persuade consumers perspectives on products and services being promoted. The institute of Practitioners in Advertising (IPA) in [4] define advertising as the most persuasive sales messages directed to the potential buyers of certain products or services at the lowest possible cost. It means, efficiency is an important requirement in advertising activities.

Advertising objectives must be compatible with overall marketing objectives, which themselves must be consistent with overall corporate objectives [5]. It is understood that advertising activities must be aligned with the objectives of marketing that are consistent with the overall goals of the company. In other words, advertising has an important role in determining the extent to which consumers will see the company as a whole, not limited to the product being advertised. The Institute of Practitioners in Advertising (IPA) in [6] provides five steps in managing good delivery on 
advertising messages as follows: (1) set the objectives; (2) set the budgets; (3) determine the advertising key message; (4) choose the right media; (5) evaluate the advertising campaign.

Social media is a medium on the internet that allows users to present themselves and interact, work together, share, communicate with other users, and form social bonds virtually[7]. Social media is an online media where users can easily participate, share and create content including blogs, social networks, wikis, forums and the virtual world [8].

According to [7], there are six characteristics of social media i.e. (1) network; (2) information; (3) archive; (4) interactivity; (5) simulation of society; (6) user-generated content. Network refers to the presence of social media provides a medium for users to connect in a technological mechanism whether the users know each other or not in the real world (offline). information becomes a commodity consumed by users. Based on this consumption activities, users form a network that ultimately consciously or not lead to networked society institutions. For the social media users, archive becomes a character that explains the information has been stored and can be accessed at any time and through any device. Interactivity means that this network not only expand friendships or followers on the internet, but also must be built by the interaction between users. Interaction in media studies is one of the differences between old media and new media. Simulation of society refers to the media is no longer presents reality, but has become its own reality, even what is in the media is more real than reality itself. User-generated content indicates that the content on social media is fully owned and is based on the contribution of the user or the account owner.

Hochman and Schwartz [9] explained that essentially, Instagram is a mobile-based application that enables users to take photos or pictures, apply the different manipulation tools to transform the appearance of images, and share them instantly with friends on different social networking sites.

Influencers are individuals or figures on social media who have a large or significant number of followers, and what they say can influence follower behavior [10]. Glucksman [11] explained three characteristic of social media influencers i.e. (1) confidence; (2) authenticity; (3) interactivity. Confidence means that when influencers trust themselves and guarantee not only themselves, but also viewers can trust their abilities. Authenticity suggest that influencers are genuine in followers' perspectives. Interactivity refers to how influencers able to collaborate with audience to gather feedbacks.

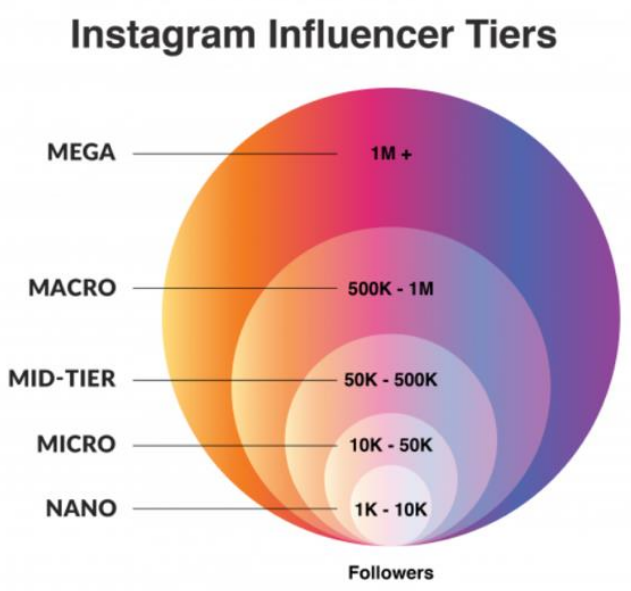

mediakix

Fig. 2. Instagram Influencer Tiers https://mediakix.com/influencermarketing-resources/influencer-tiers/

However, the potential for marketing through social media, including through Influencers, is likely to be even more lively with the presence of content creators who are called as influencers.

According to [12], there are several types of influencers i.e. (1) Nano influencers; (2) Micro influencers; (3) Mid-Tier influencers; (4) Macro influencers; (5) Mega influencers. Nano influencers have 1.000 to 10.000 followers. Micro influencers have 10.000 to 50.000 followers with $10 \%$ to $25 \%$ engagement rate. Mid-Tier influencers have 50.000 to 500.000 followers with $5 \%$ to $25 \%$ engagement rate. Macro influencers have much more followers, roughly 500.000 to 1 million followers with only $5 \%-10 \%$ engagement rate. The last one, Mega influencers being categorized as celebrities on social media or selebgram with more than 1 million followers and $2 \%$ to $5 \%$ engagement rate.

Based on influencermarketinghub.com data per 18 February 2020 there are 10 big Indonesians who have a very high level of influence on Instagram: (1) Raffi Ahmad and Nagita Slavina, 37.3 Million Followers, Engagement Rate 1.84\%; (2) Prilly Latuconsina, 33.3 million followers, engagement rate $0.88 \%$; (3) Joko Widodo, 28.5 million followers, engagement rate $1.17 \%$; (4) Natasha Wilona, 23.7 million followers, engagement rate 1.24\%; (5) Ria Ricis, 17.9 million followers, engagement rate $1.84 \%$; (6) Iqbaal Ramadan, 10 million followers, engagement rate $6.09 \%$; (7) Verrell Bramasta, 16.7 million followers, engagement rate 1.41\%; (8) Atta Halilintar, 11.8 million followers, engagement rate 2.55\%; (9) Salshabilla Adriani, 11.4 million followers, engagement rate 2.38\%; (10) Via Vallen, 21.6 million followers, $0.75 \%$ engagement rate.

\section{RESEARCH METHOD}

This study used qualitative research methods. According to [13] in social research that uses a qualitative approach, humans are involved in two positions that are the focal point of attention, namely as a subject as well as an object.

Bogdan and Taylor [14] explained that qualitative methods are research procedures that produces qualitative description data in the form of written or oral words from people and observed behavior. According to both, this 
approach is directed at the background and individual as a whole (holistic). This means that individuals must not be isolated or organized into variables or hypotheses, but need to be seen as part of a whole.

According to Denzin and Lincoln [15] qualitative research is research that uses a natural setting, with the intention of interpreting phenomena that occur and is carried out by involving various existing methods. With a variety of unique characteristics possessed, qualitative research has its own uniqueness that is different from quantitative research

Moleong [16] states that qualitative research is research that intends to understand phenomena about what is experienced by the research subject, for example behaviour, perception, motivation, action, and so forth. Holistically and by way of description in the form of words and language in a special natural context and by utilizing various natural methods.

From the descriptions above, we can understand that qualitative research methods are systematic research methods (paths) used to study or examine an object in a natural setting without any manipulation and testing hypotheses, with natural methods when the expected results of the research are not generalizations based on quantity measurements, but the meaning (in terms of quality) of the observed phenomenon.

This study uses qualitative research methods because the phenomena are not based on the deduction of a theory, but based on empirical facts in the field. The source of qualitative research data is the display in the form of spoken or written words that are observed by the researcher, and the objects observed to the details so that the meaning implied in the document or object can be captured [17]. The data source of this paper is the use of influencers in advertising on social media.

\section{RESULT AND DISCUSSION}

Based on initial search results, Instagram is the most popular social media channel used by influencers. The rest are blogs, Twitter and YouTube. The main reason why Instagram is the most favorite place for influencers is because the power of the platform places more emphasis on visual appearance.

Instagram users with a large number of followers are starting to be looked at by brands as endorsers. Because of the high turnover of money in this sector, the government even plans to collect taxes from programmakers. The Directorate General of Taxes estimated that the potential tax revenue from this business would reach Rp. 15.6 trillion per year.

Among artists is still at the top of the list of expensive influencers on Instagram. According to SociaBuzz data, the rate per post for artists reaches Rp20 million to Rp10 million. Indeed, not all influencers set high prices. There is also a set price of hundreds of thousands of posts. Everything depends on the number of followers on Instagram and the price set by the celebrity himself.

Instagram as a platform for sharing photos and short videos is the right location to visually introduce products. Instagram is easier to understand and spoil your eyes.

In addition, many studies have shown that influencer marketing, especially micro-influencers, is more original than celebrities in terms of advertising products. They have their own style to judge a product. Not infrequently, brands use an approach that suits the influencer itself.

The development of social media in recent years brings communication through new channels based on technology. The presence of public figures or who are often called influencers in the realm of social media also opens business opportunities for content creators on social media.

Social media is also developing as a realm of advertising, promotion through creative ways for brands.

A person who is judged to influence his audience is considered to have an impact on a product or brand. See, the phenomenon of the brand hook influencers when it will introduce new products, more and more.

This data reinforces why brands choose channels such as paid social media or influencer marketing to reach consumers because they are considered more effective.

Influencer marketing can be interpreted as identifying, researching, involving, and supporting individuals or groups that create high-impact conversations with customers about brands, products, or services. Influencer posts include social media, blogs, or video channels.

Just imagine, if an influencer uploads about a product and is watched up to 100,000 times, the value that might be obtained could reach tens of millions. However, this value is still considered cheaper than marketing in the mainstream media.

A good influencer is usually able to create content about a product so well that it looks like they really use it. That way, their followers don't realize that what they see is actually advertising [18]. This makes influencers who initially as content creators eventually become influencer marketing who determine the decisions of social media users who are also consumers of a product or service. Now many product brands are making influencers to increase sales conversions.

The cost of advertising through influencers only requires 10 percent compared to the cost of producing and displaying advertisements on TV [1]. Based on this statement, it will help the company's financial situation because they can reduce their advertising costs and maximize the budget in other strategic sectors.

Based on a GetCraft survey of 43 brand holders, $16 \%$ of them plan to increase their budget for digital advertising to more than $50 \%$ of their total advertising expenditure. GetCraft estimates that $31 \%$ of brand holder's advertising budget will turn to native advertising [18]. In addition to saving costs, companies are willing to pay more to advertise on social media. That way, the profession as influencers in the future will be increasingly in demand because companies will utilize as many influencer services as possible in their advertising activities so they can reach the right target consumers of the products or services they offered.

Besides being relatively cheaper, the advantage of advertising through other influencers is trust. Nielsen, stated that the recommendations of friends and family get a high place of trust in the community. In addition, the recommendations or reviews conducted by foreigners on the internet also have a significant effect [19]. the presence of influencers can also make the products or services offered 
easier to trust. This is supported by the ability of influencers to maintain reputation, build good relationships with followers, and also established the authenticity of the products or services to their followerskemp.

The greater the company's needs for influencer services, the higher the competition is due to the increasing number of people who choose the profession as an influencer. One of the challenges is how influencers able to produce quality content on an ongoing basis. This requires commitment and creativity which is certainly not an easy thing to do. Hidayatullah in [18] explained that there are five determinants of influencer rates, namely quality of content, personal brand, number of followers, client's financial ability, and deadlines.

Influencers has become a very promising business model with large opportunities. There are agents who become their facilitators with advertisers such as Mamorae, BuzzHero, SociaBuzz and influencermarketinghub.com.

Influencermarketinghub in his study found, there are more than 230 platforms and new agencies that accommodate these influencers. Everything was born in the last 2 years, when this trend is rising.

Even though it is needed, the existence of these third parties can be a barrier such as late payment because there must be additional procedures before the influencers receive the payment.

In addition, there are also challenges ahead of influencers income taxes, and the last is other influencers who will be a threat because the more influencers the audience will also be divided.

Although marketing by influencers is expected to become a bigger business, and brands are better equipped than ever to bombard influencers with money. But another threat arises: companies become more careful in choosing influencers

In addition, several cases of influencer fraud make people fear and distrust. Apart from the consumer side, threats come to content creators.

The demand for content continues to increase and the number of other influencers more and more provoking competition to grow among middle and lower level influencers, the income will be increasingly difficult to obtain for most influencers.

An overly saturated market coupled with persistent content requests made some influencers give up and eventually chose to become a regular user again. Some even feel bored with being a marketing influencer on Instagram.

Apart from the public side and influencers, threats from Instagram emerge. For example, in technical matters, Instagram, which no longer arranges its main page with posts in chronological order, has a negative effect on influencers' accounts. Influencers and followers become less connected and attached.

\section{CONCLUSION}

The growth of social media like Instagram, Facebook, Twitter, and YouTube has become a gold mine for influencers. Affordable price is one of the main reasons why marketing via influencers is so popular these days.

Despite the opportunities, there are also some threats such as late payments, how to provide quality content consistently, income tax, and the emergence of other influencers.

\section{REFERENCES}

[1] Zaenudin, Ahmad. Influencer di Media Sosial, Penantang Tangguh Iklan Konvensional [Online]. 2018 Available: https://tirto.id/influencer-di-media-sosial-penantang-tangguh-iklankonvensional-cEfr, accessed on 18 February 2020

[2] Morrisan, M. A. Periklanan komunikasi pemasaran terpadu. Kencana. 2015 .

[3] O’Guinn, T., Allen, C., Semenik, R. J., \& Scheinbaum, A. C. Advertising and Integrated Brand Promotion. Cengage Learning. 2014.

[4] Jefkins, F. Periklanan. Jakarta: Erlangga. 1997.

[5] De Pelsmacker, P. Integrated Marketing Communications: A Primer. Taylor \& Francis. 2004

[6] Hermawan, A. Komunikasi pemasaran. Jakarta: Erlangga. 2012.

[7] Nasrullah, R. Media sosial: Perspektif komunikasi, budaya, dan sosioteknologi. Bandung: Simbiosa Rekatama Media, 2015

[8] Romli, A. S. M., \& Syamsul, A. Jurnalistik online: panduan praktis mengelola media online. Bandung: Nuansa Cendekia. 2012.

[9] Ting, H., Ming, W. W. P., de Run, E. C., \& Choo, S. L. Y. Beliefs about the use of Instagram: An exploratory study. International Journal of Business and Innovation, 2(2), 15-31, 2015.

[10] Hariyanti, N. T., \& Wirapraja, A. Pengaruh Influencer Marketing Sebagai Strategi Pemasaran Digital Era Moderen (Sebuah Studi Literatur). Eksekutif, 15(1), 133-146, 2018.

[11] Yunus, U. Digital branding: teori dan praktik. Bandung: Simbiosa Rekatama Media. 2019

[12] Arief, N. Public Relations In The Era Of Artificial Intelligence. Bandung: Simbiosa Rekatama Media. 2019.

[13] Bajari, A. Metode penelitian komunikasi: prosedur, tren, dan etika. Bandung: Simbiosa Rekatama Media. 2015.

[14] Prastowo, A. Metode Penelitian Kualitatif dalam Perspektif Rancangan Penelitian. Jogjakarta: Ar-Ruzz Media. 2012.

[15] Djam'an Satori, A. K. Metode Penelitian Kualitatif. Alfabeta, Bandung. 2010.

[16] Herdiansyah, H. Metodologi penelitian kualitatif untuk ilmu-ilmu sosial. Jakarta: Salemba Humanika. 2010.

[17] Arikunto, S. Prosedur Penelitian Suatu Pendekatan Praktik. Jakarta: Rineka Cipta. 2010.

[18] Setyowati, Desy. Jadi Musim Panen Influencer Media Sosial [Online]. 2018 Available: https://katadata.co.id/berita/2018/07/14/2018-jadimusim-panen-influencer-media-sosial, accessed on 18 February 2020

[19] Jambidi, Putri. Influencer Media Sosial Lebih Berpengaruh Dibanding Saluran Media Konvensional [Online]. 2018. Available: https://www.biem.co/read/2018/02/10/13500/influencer-mediasosial/. accessed on 18 February 2020 